УДК 342.95:347.998.85

DOI https://doi.org/10.32837/pyuv.v0i2(31).573

\author{
Л. П. Ішук \\ orcid.org/0000-0003-2579-5092 \\ аспірант кафедри крилінального права та правосуддя \\ Міжнародного еконоліко-гуманітарного університету ілені акаделіка Степана Дел'янчука
}

\title{
ОСОБЛИВОСТІ РОЗГЛЯДУ ПУБЛІЧНО-ПРАВОВИХ СПОРІВ У ФІСКАЛЬНІЙ СФЕРІ В АДМІНІСТРАТИВНОМУ СУДОЧИНСТВІ
}

Ефективне публічне адміністрування у фіскальній сфері є надзвичайно важливим. Держава не може існувати без відповідного забезпечення фінансовими ресурсами, тому реалізація політики у сфері регулювання доходів і видатків для будь-якої держави є невід'ємним елементом iㅣ функціонування.

Розвиток системи органів публічної адміністрації у фіскальній сфері передбачає здійснення належного урядування, адже громадяни України здійснюють владу «безпосередньо і через органи державної влади й органи місцевого самоврядування» [1]. У цьому аспекті важливою є наявність певного балансу між довірою громадян до органів державної влади й органів державної влади до громадян. Держава має «запровадити внутрішні процедури, які посилюють прозорість і ясність дій органів державної влади, мінімізують ризик помилок і сприяють юридичній визначеності» [2].

Будучи діяльністю уповноважених органів державної влади, спрямованою на виконання завдань i функцій держави, публічне адміністрування у фіскальній сфері залежить не лише від правового регулювання суспільних відносин, що виникають під час реалізації політики у сфері регулювання доходів і видатків держави, але й від інтерпретації норми права контролюючими органами, дій посадових осіб таких органів державної влади, які iï реалізують і діяльність яких не позбавлена суттєвих недоліків. Незважаючи на те, що «органи державної влади та їхні посадові особи зобов' язані діяти лише на підставі, в межах повноважень та у спосіб, що передбачені Конституцією та законами України» [1], на практиці виникає чимало публічно-правових спорів у фіскальній сфері, пов'язаних із застосуванням правових норм.

Проблемам визначення сутності публічно-правового спору, розгляду публічно-правових спорів у порядку адміністративного судочинства, розгляду окремих публічно-правових спорів у фіскальній сфері були присвячені багато праць учених. Так, зокрема, О.І. Корчинський і Н.Б. Писаренко досліджували правові засади організації адміністративного судочинства [3; 4], О.Ю. Щербакова, В.О. Курило - окремі аспекти вирішення податкових публічно-правових спорів [5; 6], О.В. Рой правові акти суб'єктів владних повноважень як предмету публічно-правового спору [7]. Однак низка питань про публічно-правові спори у фіскальній сфері залишаються не вирішеними.

Реформування, розвиток і модернізація системи публічного адміністрування у фіскальній ссрері зумовлює необхідність пошуку забезпечення оптимального балансу публічних і приватних інтересів, адже саме публічні та приватні інтереси сприяють виникненню, зміні та розвитку суспільних відносин у державі. Особливістю фінансових правовідносин $є$ те, що дії фізичних і юридичних відносин направлені насамперед на реалізацію публічного інтересу, що виникає у зв'язку з появою публічних і приватних потреб. Виконуючи свій конституційний обов'язок по сплаті податків i зборів, юридичні та фізичні особи не лише забезпечують надходження до державного та місцевого бюджетів, але й отримують певні блага для задоволення публічних і приватних потреб. Саме «права і свободи людини та їх гарантії визначають зміст і спрямованість діяльності держави» [1], й одним із головним обов'язків держави $є$ «утвердження i забезпечення прав і свобод людини» [1], тобто держава має забезпечити створення таких умов, за яких задовольняються інтереси суспільства.

Виходячи з конституційного права кожного на «оскарження в суді рішень, дій чи бездіяльності органів державної влади, органів місцевого самоврядування, посадових і службових осіб» [1], можна констатувати той факт, що публічно-правові спори у фіскальній сфері - це юридичні конфлікти, які виникають у зв'язку з реалізацією публічної влади у цій сфері [8, с. 6], сторонами яких є фізичні та юридичні особи і суб'єкт, наділений публічно-владними повноваженнями. До таких публічно-владних повноважень слід віднести повноваження щодо правового регулювання, надання адміністративних послуг, здійснення нагляду та контролю, управління об'єктами, а також інші повноваження щодо вирішення питань про права, свободи, інтереси фізичних, юридичних осіб, за винятком законодавчих, а також повноважень щодо здійснення правосуддя [8, с. 15].

Публічно-правові спори у фіскальній сфері завжди пов'язані з наявністю суперечностей між суб'єктами цих правових відносин щодо реалізації їхніх прав, свобод, інтересів, а також обов'яз- 
ків [8, с. 10], тобто предметом таких спорів є рішення, дії чи бездіяльність органів державної влади, що реалізують політику у сфері регулювання доходів і видатків держави.

Відповідно до Класифікатора категорій адміністративних справ, затвердженого рішенням Ради суддів адміністративних суддів від 31 жовтня 2013 р. № 114, до публічно-правових спорів у фіскальній сфері віднесено «спори із приводу реалізації публічної фінансової політики», «спори із приводу адміністрування податків, зборів, а також контролю за дотриманням вимог податкового законодавства», "спори із приводу реалізації державної політики у сфері економіки щодо митної справи» [9].

До спорів із приводу реалізації публічної фінансової політики слід віднести спори щодо валютного регулювання і валютного контролю, спори щодо грошового обігу та розрахунків в Україні, спори, що виникають у бюджетній системі та в бюджетному процесі, спори, пов'язані з державним боргом, спори у сфері фінансових послуг, спори у сфері державного фінансового контролю, спори щодо процедур здійснення контролю Рахунковою палатою. До спорів із приводу адміністрування податків, зборів, а також контролю за дотриманням вимог податкового законодавства слід віднести спори щодо реалізації податкового контролю, щодо погашення податкового боргу, щодо адміністрування окремих податків і зборів, а також за зверненням податкових органів (визнання оспорюваних правочинів недійсними та застосування визначених законодавством заходів, пов'язаних із визнанням правочинів недійсними, стягнення в дохід держави коштів, отриманих за нікчемними договорами, припинення юридичної особи (припинення підприємницької діяльності фізичної особи - підприємця)) [9].

Кількість позовних заяв і справ із приводу спорів у фіскальній сфері, що надходять до судів різних інстанцій, щороку зростає. Так, наприклад, кількість позовних заяв і справ, які надійшли до місцевих адміністративних судів у 2019 р., становила 14140 у сфері публічної фінансової політики та 37983 у сфері податків і зборів, що становить 6\% і 17\% від всієї кількості справ відповідно. Кількість позовних заяв і справ, що надійшли до окружних адміністративних судів у 2019 р., становила 12237 у сфері публічної фінансової політики та 33815 у сфері податків і зборів - 8\% і 21\% від всієї кількості справ відповідно. Упродовж 2019 р. апеляційні адміністративні суди переглянули 5886 рішень (постанов) із приводу реалізації державної політики у сфері економіки та публічної фінансової політики, з яких змінено чи скасовано 1707 і 10815 рішень із приводу податків і зборів, із яких змінено чи скасовано 2383 рішень. Крім того, до Касаційного адміністративного суду як касаційної інстанції у 2019 р. надійшло 13965 скарг і справ зі спорів, що виникають у сфеpi податків і зборів, і 4373 у сфері реалізації публічної фінансової політики. I серед цієї кількості касаційних скарг переглянуто 5183 рішення у сфері податків і зборів і 3820 рішень у сфері публічної фінансової політики, кожне третє та кожне друге відповідно з яких змінено чи скасовано [10].

Таким чином, аналіз статистичних даних діяльності адміністративних судів в Україні дає можливість зробити висновки, що майже третину всіх справ, які розглядаються в порядку адміністративного судочинства, становлять саме публічно-правові спори у фіскальній сфері. Спорів із приводу адміністрування податків, зборів платежів, а також контролю за дотриманням вимог податкового законодавства виникає найбільше.

Наявність такої кількості різних спорів у фіскальній сфері, що виникають між юридичними та фізичними особами із суб'єктами владних повноважень, зумовлює особливості розгляду цієї категорії публічно-правових спорів. Ці спори не завжди вдається вирішити оперативно, а судові процеси можуть бути досить тривалими і затягнутися на роки. Водночас іншою особливістю адміністративного судочинства у публічно-правових спорах у фіскальній сфері є те, що для повного, всебічного й об'єктивного розгляду таких спорів судді мають не лише володіти юридичними знаннями, а й розуміти особливості бухгалтерського та податкового обліку, валютного і грошового обігу, бюджетного процесу та фінансових послуг. Аналіз судових рішень у цій сфрері свідчить і про те, що сформувати судову практику надзвичайно важко, враховуючи постійні зміни до чинного законодавства. Так, наприклад, податкове законодавство щорічно змінюється, прогалин у податковому законодавстві виникає тим більше, чим динамічніше розвиваються суспільні відносини $[11$, с. 14], а це істотно впливає на судочинство.

На нашу думку, до основних проблем виникнення публічно-правових спорів у фіскальній сфері можна віднести неоднозначне застосування норм права, процедурні порушення контролюючими органами, недотримання посадовими особами контролюючих органів норм чинного законодавства при здійсненні ними своїх повноважень. Так, наприклад, одним із предметів публічно-правових спорів в оподаткуванні є порушення порядку призначення та проведення перевірок, оскарження наказів на призначення перевірок, оскарження результатів перевірок, зокрема податкових повідомлень-рішень [12-14].

Крім того, під час вирішення спорів виникає багато питань 3 оцінкою відомостей, які надаються контролюючими органами, часто ці відомості не повною мірою відображають всю інформацію, необхідну для розгляду. Так, наприклад, 
покладення обов'язку доказування на контролюючі органи їх рішень у спорах із приводу адміністрування податків, зборів, а також контролю за дотриманням вимог податкового законодавства нерідко призводить до того, що в розглядуваній адміністративним судом справі не вистачає всіх необхідних доказів, і суду доводиться діяти без максимально повної інформації щодо дій платника податків і його контрагентів. Як результат, ускладнюється сам процес доказування і виявлення вчинених платником податків зловживань, що мають податкові наслідки $[11$, с. 6]. Вважаємо, що для повного, всебічного й об'єктивного розгляду такої категорії справ на законодавчому рівні слід передбачити можливість судді мати доступ до державних реєстрів у зв'язку із розглядом конкретної справи.

Також часто до судів продовжують надходити справи, у яких уже є напрацьована чітка правова позиція, а це свідчить про те, що контролюючі органи не використовують у своїй повсякденній діяльності судову практику, яку необхідно враховувати і яка може сприяти регулюванні суспільних відносин у фіскальній сфері. Так, наприклад, у судовій практиці є безліч однотипних рішень, коли судові органи скасовували рішення контролюючих органів із посиланням на презумпцію правомірності рішення платника податку. Саме принцип презумпції правомірності рішень платника податків $є$ не лише механізмом забезпечення балансу між інтересами держави та платника податків при застосуванні норм права, а й універсальним способом подолання певних колізій між нормами ПК України [15, с. 138]. Водночас окремі платники податків, зловживаючи своїми правами на оскарження рішень і дій контролюючих органів, використовують процедуру саме судового оскарження для ухилення від виконання своїх податкових обов'язків перед бюджетом внаслідок автоматичного переведення таких зобов'язань у статус неузгоджених із початком процедури оскарження [11, с. 15].

Привертає увагу також проблема, коли схожі спори або спори, що виникли з аналогічних підстав з одним і тим самим суб'єктом владних повноважень чи його відокремленими структурними підрозділами, що регулюються одними й тими самими нормативно-правовими актами та містять аналогічні вимоги, на практиці вирішуються по-різному. Враховуючи той факт, що КАС України передбачено існування типових і зразкових адміністративних справ, Верховний Суд України ухвалив лише 17 рішень у зразкових справах, серед яких 4 рішення із приводу реалізації державної політики у сфері економіки та публічної фінансової політики та 4 рішення із приводу адміністрування податків, зборів, платежів, а також контролю за дотримання вимог податкового законодавства [16, с. 4].
Для прикладу можна навести зразкові справи Верховного Суду України із приводу адміністрування податків, зборів, платежів, а також контролю за дотримання вимого податкового законодавства, а саме: справу № 812/292/18 (Пз/9901/22/18) [17] про скасування рішення щодо застосування штрафних санкцій і застосування пені за несплату або несвоєчасну сплату єдиного внеску та справу № 520/3939/19 (Пз/9901/10/19) [18] про оподаткування самозайнятої особи, яка одночасно зареєстрована як фізична особа - підприємець. У цих справах Верховний Суд України визначив «ознаки типових справ, обставини зразкової справи, що зумовлюють типове застосування норм матеріального права та порядок застосування таких норм; обставини, які можуть впливати на інше застосування норм матеріального права, ніж у зразковій справі» [17; 18].

Погоджуємося із думкою Н.Б. Писаренко, за якою правосуддя в адміністративних справах має бути доступним, у розгляді справ адміністративних суд повинен застосовувати закон однаково для всіх, а остаточні рішення не можуть братися під сумнів і мають неухильно виконуватися [4, с. 7]. Вважаємо, що розгляд більшої кількості зразкових справ і прийняття по таких справах рішень може сприяти швидкому розгляду справ адміністративними судами, а існування єдиної судової практики підвищить задоволеність громадян діяльністю судів, створить підгрунтя до поновлення довіри до суду, адже сьогодні громадяни України найчастіше недовіру висловлюють саме державному апарату (чиновникам) (77\%) і судовій системі загалом $(76 \%)$, місцевим судам $(71 \%)$, Верховному Суду (64\% ) [19]. Адміністративне судочинство повинно прагнути досягти певних стандартів і втілювати їх у життя [3, с. 156].

Складність розгляду публічно-правових спорів у фіскальній сфері також пов'язана 3 наявністю численних прогалин у матеріальному праві, що перешкоджають ефективній діяльності адміністративних судів щодо захисту прав, свобод та інтересів фізичних, юридичних осіб у сфері публічно-правових відносин, змушують суддів заповнювати ці прогалини безпосередньо у своїх рішеннях без достатнього законодавчого підгрунтя; призводять до необгрунтованих і неправосудних рішень і загалом спричиняють неоднорідність i суперечливість судової практики [8, с. 17]. Ефективність правосуддя в адміністративних справах залежить від того, наскільки точно і реально визначені в законі його завдання і цілі, і від того, чи достатньо процесуальних та інших засобів (гарантій) для їх досягнення [20, с. 3].

Отже, як висновок, варто зазначити, що для підвищення ефективності діяльності адміністративних судів і забезпечення прав, свобод та інтересів фізичних і юридичних осіб у публічно-пра- 
вових відносинах у фіскальній сфері необхідно вдосконалювати не лише чинне законодавство у напрямку створення несуперечливого матеріального та процесуального права, але й формувати єдину судову практику для правильного й об'єктивного вирішення всіх публічно-правових спорів.

\section{Jimepamypa}

1. Конституція України від 28 червня $1996 \mathrm{p}$. № 254к/96-BP. URL: https://zakon.rada.gov.ua/laws/ show $/ 254 \%$ D0 $\%$ BA $/ 96-\%$ D0 $\%$ B2 $\%$ D1 $\%$ 80\#Text.

2. Рисовський проти України: рішення Європейський суд з прав людини від 20 жовтня $2011 \mathrm{p}$. (Заява № 29979/04). URL: https://zakon.rada.gov.ua/ laws/show/974_854\#Text.

3. Корчинський О.І. Правові засади організації адміністративного судочинства в Україні : дис. ... канд. юрид. наук : 12.00.07 / Національний університет «Львівська політехніка», Львів, 2018. 185 с.

4. Писаренко Н.Б. Концептуальні основи адміністративного судочинства в Україні : автореф. дис. ... канд. юрид. наук : 12.00.07 / Національний юридичний університет імені Ярослава Мудрого, Міністерство освіти і науки України. Харків, 2019. 38 с.

5. Щербакова О.Ю. Предмет доказування в податкових спорах : автореф. дис. ... канд. юрид. наук : 12.00.07 / Нац. юрид. ун-т ім. Ярослава Мудрого. Харків, $2015.20 \mathrm{c}$.

6. Курило В.О. Правова природа процедур вирішення податкових спорів: порівняльно-правовий аналіз : автореф. дис. ... канд. юрид наук : 12.00.07 / Запорізький національний університет, Запоріжжя, 2017. 22 с.

7. Рой О.В. Правові акти суб'єктів владних повноважень як предмет публічноправового спору : дис. .. канд. юрид. наук : 12.00.07 / Науково-дослідний інститут інформатики і права Національної академії правових наук України, Київ, 2019. 269 с.

8. Хлібороб Н.Є. Публічно-правовий спір як предмет юрисдикційної діяльності адміністративного суду : автореф. дис. ... канд. юрид. наук : 12.00.07 / Національний університет «Львівська політехніка» Львів, $2012.22 \mathrm{c}$.

9. Про Класифікатор категорій адміністративних справ та Методичні роз'яснення щодо його застосування: рішення Ради суддів адміністративних судів від 31 жовтня 2013 р. № 114. URL: https://zakon.rada.gov. ua/rada/show/v0114413-13\#Text.

10. Аналіз стану здійснення правосуддя адміністративними судами у 2019 році. URL: https://supreme.court.gov.ua/userfiles/media/Analiz Admin sudu 2019.pdf.

11. Сахно Д.С. Зловживання правом у податкових правовідносинах : автореф. дис. ... канд. юрид. наук : 12.00.07 / Університет державної фіскальної служби України. Ірпінь, 2019. 23 с.

12. Постанова Третього апеляційного адміністративного суду від 22 січня 2020 р. № 160/7155/19. URL: http://www.reyestr.court.gov.ua/Review/87128300.

13. Постанова Верховного Суду України від 21 лютого 2020 р. № 826/17123/18. URL: http://www.reyestr.court.gov.ua/Review/87929522.

14. Постанова Верховного Суду України від № 140/391/19 від 07 листопада 2019 p. URL: http://www.reyestr.court.gov.ua/Review/85613433.

15. Дуліба Є.В. Фіскальна функція держави: адміністративно-правовий аспект : монографія / за заг. ред. В.І. Курила. Ніжин : НДУ ім. Миколи Гоголя, 2018. 355 c.
16. Зразкові справи (аналітичний огляд) Верховного Суду України. Київ, 2020. Вип. 2. 30 с. URL: https://supreme.court.gov.ua/userfiles/media/ Zrazkovi spravi 1.pdf.

17. Постанова Верховного Суду України від 06 листопада 2018 р. Справа № 812/292/18 (Пз/9901/22/18). URL: http://reyestr.court.gov.ua/Review/77911136.

18. Рішення Верховного Суду від 02 вересня 2019 p. № 520/3939/19 (№ Пз/9901/10/19). URL: http://www.reestr.court.gov.ua/Review/84077152.

19. Оцінка громадянами ситуації в країні, piвень довіри до виконавчих та правоохоронних органів влади, оцінка діяльності Уряду (лютий 2020 р.). URL: http://razumkov.org.ua/napriamky/sotsiologichnidoslidzhennia/otsinka-gromadianamy-sytuatsiiv-kraini - riven-doviry-do-vykonavchykh-tapravookhoronnykh-organiv-vlady-otsinka-diialnostiuriadu-liutyi-2020r.

20. Соловйов I.M. Проблеми підвищення ефективності діяльності адміністративних судів : автореф. дис. ... канд. юрид. наук : 12.00 .10 / Нац. юрид. ун-т ім. Ярослава Мудрого. Харків, 2015. 20 с.

\section{Анотація}

Ішук Л. П. Особливості розгляду публічно-правових спорів у фіскальній сфері в адміністративному судочинстві. - Стаття.

Стаття присвячена дослідженню особливостей розгляду публічно-правових спорів у фіскальній сфеpi в адміністративному судочинстві. Зазначено, що публічне адміністрування у фіскальній сфері залежить не лише від правового регулювання суспільних відносин, які виникають під час реалізації політики у сфері регулювання доходів і видатків держави, але і від інтерпретації норми права контролюючими органами, дій посадових осіб таких органів державної влади, які її реалізують і діяльність яких не позбавлена суттєвих недоліків.

Проведено аналіз статистичних даних діяльності адміністративних судів дав можливість зробити висновок, що майже третину всіх справ, які розглядаються в таких судах всіх інстанцій, становлять публічно-правові спори у фіскальній сфері. Виділено різновиди публічно-правових спорів у фіскальній сфері, до яких віднесено спори із приводу реалізації публічної фінансової політики, із приводу адміністрування податків, зборів, а також контролю за дотриманням вимог податкового законодавства, із приводу реалізації державної політики у сфері економіки щодо митної справи.

Акцентовано увагу на основних проблемах виникнення таких публічно-правових спорів, до яких віднесено: неоднозначне застосування норм права, процедурні порушення контролюючими органами, недотримання посадовими особами контролюючих органів норм чинного законодавства при здійсненні ними своїх повноважень, неврахування контролюючими органами напрацьованої чіткої правової позиції судової практики, існування невеликої кількості типових і зразкових справ. Особливостями ж розгляду визначено те, що спори не завжди вирішуються оперативно, а судові процеси можуть бути тривалими, для повного, всебічного й об'єктивного розгляду таких спорів судді мають володіти не лише юридичними знаннями, а й розуміти особливості бухгалтерського та податкового обліку, валютного і грошового обігу, бюджетного процесу та фінансових послуг. Сформувати судову практику надзвичайно важко з огляду на постійні зміни до чинного законодавства у фіскальній сфері. 
Автор дійшов висновку, що для підвищення ефективності діяльності адміністративних судів і забезпечення прав, свобод та інтересів фізичних і юридичних осіб у публічно-правових відносинах у фіскальній сфері необхідно вдосконалювати не лише чинне законодавство в напрямку створення несуперечливого матеріального та процесуального права, але й формувати єдину судову практику для правильного й об'єктивного вирішення всіх публічно-правових спорів.

Ключові слова: публічно-правовий спір, фіскальна сфера, адміністративне судочинство, спори із приводу реалізації публічної фінансової політики, спори із приводу адміністрування податків, зборів, а також контролю за дотриманням вимог податкового законодавства, спори із приводу реалізації державної політики у сфері економіки щодо митної справи.

\section{Summary}

Ishchuk L.P. The peculiarities of consideration of disputes in the fiscal field in administrative proceedings. Article.

The article is devoted to the investigation of peculiarities of consideration of disputes in the fiscal field in administrative proceedings. It is noted that public administration in the fiscal field depends not only on the legal regulation of public relations resulting from the implementation of the State's revenue and expenditure policy but also on the interpretation of the rule of law by the supervisory authorities, the actions of officials of such State authorities are carried out in a manner that is not without significant shortcomings.

An analysis of the statistical data on the activities of the administrative courts led to the conclusion that almost one-third of all cases are disputes in the fiscal filed, which give rise to certain features of their consideration. It is allocated the varieties of disputes in the fiscal field, which include disputes over the implementation of public financial policy, disputes over the administration of taxes, fees, as well as the control of compliance with the requirements of tax legislation, disputes over the implementation of state economic policy with regard to customs.

It is focused the attention on the main problems of the emergence of disputes and specificities of the judicial proceedings. Such problems include the ambiguous application of the law, procedural violations by the supervisory authorities, non-compliance by the officials of the supervisory authorities with the law in the exercise of their powers, the failure of the supervisory authorities to take into account the clear legal position of the jurisprudence and the existence of a small number of typical and exemplary cases. The specificities of the judicial proceedings are that disputes are not always resolved expeditiously and trials can be lengthy, judges must possess not only the legal knowledge but understand also the peculiarities of tax accounting, currency and monetary circulation, budget process and financial services, also it is hard to form a judicial practice, given the constant changes in the current fiscal legislation.

It is concluded that in order to enhance the efficiency of the administrative courts and to safeguard the rights, freedoms, and interests of natural and legal persons in fiscal relations it is necessary to improve not only existing legislation in the direction of creating coherent substantive and procedural law but also to establish a uniform judicial practice for a correct and objective decision by all in disputes.

Key words: public dispute, fiscal field, administrative proceedings, disputes over the implementation of public financial policy, disputes over the administration of taxes, fees, as well as control over compliance with tax legislation, disputes over the implementation of state policy in the field of economics on customs affairs. 